Japanese Journal of Herpetology 10(2) : 33-38. 1983.

\title{
Taxonomic Reassignment of the Colubrid Snake, Opheodrys kikuzatoi, from Kume-jima Island, Ryukyu Archipelago
}

\author{
Masanao TOYAMA
}

\begin{abstract}
The taxonomic status of Opheodrys kikuzatoi, a rare snake described from a single specimen, confined to Kume-jima, the Okinawa Islands, was examined on the basis of three specimens, including two new specimens. The species proved to be not a member of the genus Opheodrys. The characteristics of the Chinese members of the genus Opis. thotropis, i.e., dorsally directed nostril, single prefrontal, pentagonal frontal, and posteriorly strongly keeled dorsal scales, all applied to the examined specimens. Thus, kikuzatoi was removed from Opheodrys and allocated to Opisthotropis.
\end{abstract}

Okada and Takara (1958) described one specimen of a colubrid snake from Kume-jima, a small Island of the Okinawa Group, Ryukyu Archipelago, as a new species, Liopeltis kikuzatoi. This assignment was based on its resemblance to Liopeltis semicarinatus from Okinawa Islands. Later, Koba et al. (1959) and Nakamura and Uéno (1963) adopted the generic name Opheodrys for kikuzatoi, as well as for two other species of Japanese Opheodrys, O. semicarinatus and O. herminae. Recently Cundall (1981) revised the genus Opheodrys and placed the Asian members of this genus in Entechinus. In his list, however, kikuzatoi was neglected, probably because the presence of this unique form has been little known outside of Japan. If the idea that kikuzatoi is a congener of semicarinatus, as accepted by previous authors, is valid, then kikuzatoi would also be a member of the genus Entechinus. No detailed studies, however, have been made on this problem.

No additional specimens of Opheodrys kikuzatoi had been collected from any island of the Okinawa Group, until Mr. K. Kikuzato, the collector of the holotype, sent the second specimen of this species to our museum in 1981. The specimen had been collected from Kume-jima, the type locality of this species. In 1982 I myself made a collecting trip to Kume-jima and captured a third specimen. This specimen was found in the water of a mountain stream (Fig. 1). This was an unusual situation, when compared with Entechinus semicarinatus or E. herminae. Subsequent examination of the three available specimens showed that this species is distinct from the members of the genus Entechinus and belongs to the genus Opisthotropis. This

Okinawa Prefectural Museum, Shuri Onakacho, Naha, Okinawa, 903 Japan. 903 沖縄県那龩市首里大中町, 沖縄県立博物館 
paper re-assigns the species to the genus Opisthotropis, amending the original description.

Opisthotropis kikuzatoi (Okada et Takara, 1958)

Specimens examined.

Holotype: Faculty of Agriculture, University of the Ryukyus. No. 1. adult male, collected in the upper reaches of the Shirasegawa River, at a point $1,000 \mathrm{~m}$ from the summit of Mt. Uegusuku-dake (309m), Kume-jima Island, Ryukyu Archipelago by K. Kikuzato on 15 September 1956.

Second Specimen: Okinawa Prefectural Museum (OPM) H 005, adult female, from the same locality as the holotype on 20 August 1965. Collector unknown.

Third Specimen: OPM H 665, adult male from the same locality as the holotype by M. Toyama on 19 September 1982.

Diagnosis. This aquatic snake resembles Opisthotropis maxwelli in having a single nasal, two preoculars, and two postoculars, but differs from it in the following characters: supralabials six, the fourth in contact with the eye; body scale rows 15 , scales smooth on the trunk but keeled on the tail; ventrals 180 - 183 , subcaudals 69-73.

General characteristics and lepidosis. (Features in parentheses for the additional specimens, OPM H 005, OPM H 665) Head slightly wider than neck; snout short, rounded, depressed, feebly protruding beyond lower jaw; rostral distinctly broader than deep, widely in contact with internasals; internasals four-sided, slightly wider than long (small scale between internasals in OPM H 005); their median suture $1 / 2$

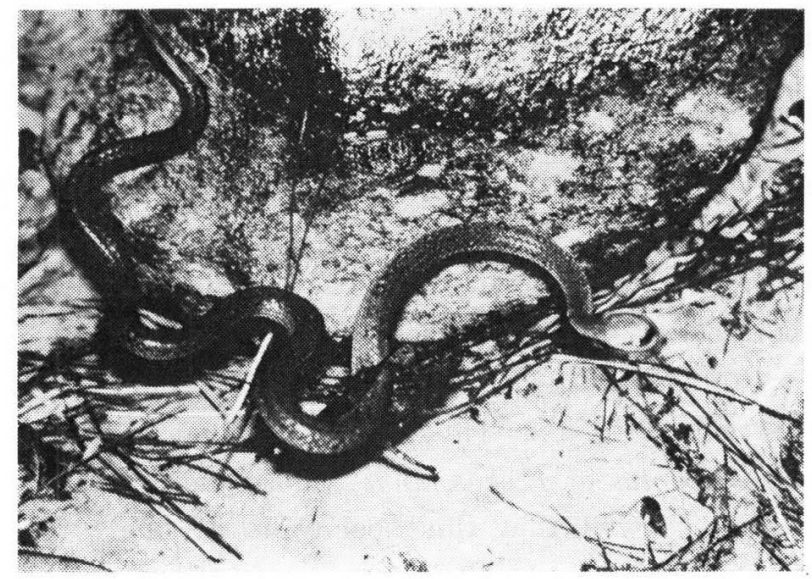

Fig. 1. A male Opisthotropis kikuzatoi (OPM H 665), swimming in a shallow portion of the Shirasegawa River, Kume-jima Island. times the length of the suture with the nasal, $1 / 3$ times the length of the suture with the prefrontal; prefrontal single, large, 2.5 times as broad as long (irregular and incomplete suture in the right side of prefrontal of the holotype and in the middle of OPM H 005 , Fig. 2, A and B); frontal large, as broad as long, three times the width of the supraocular, pentagonal, tapered posteriorly, a suture with prefrontal and parietal; parietals modera- 


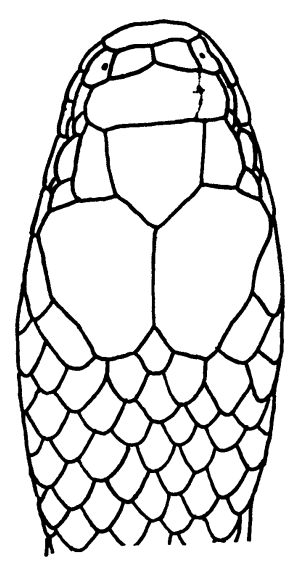

A

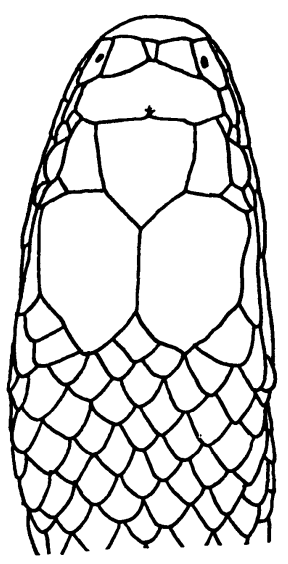

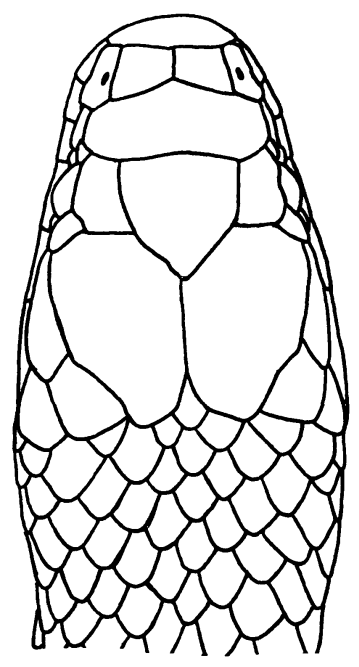

C

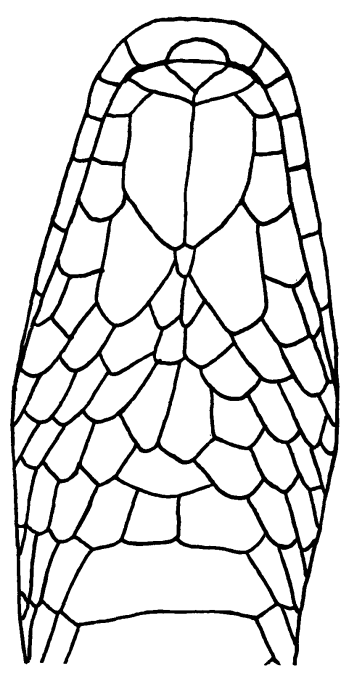

D

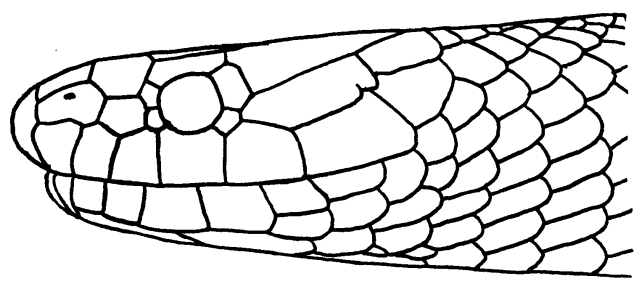

$\mathbf{E}$

$5 \mathrm{~mm}$

\section{B}

Fig. 2. Head of Opisthotropis kikuzatoi. A: Dorsal view of the holotype (adapted from Okada and Takara, 1958); B: Dorsal view of OPM H 005; C-E: IDorsal (C), ventral (D) and lateral (E) views of OPM H 665.

tely long, broad, their median suture as long as the frontal; supraocular two times longer than broad; two preoculars (including subpreocular in the original description); two postoculars.

Nasal single, broader than loreal; nostril small, ellipsoidal, directed dorsally, located in upper part; no postnasal; loreal a little longer than deep, $2 / 3$ times as 
large as nasal, slightly smaller than eye diameter, which is as long as distance between nasal and eye; pupil round; two preoculars; six supralabials, fourth entering the orbit (in the original description the number of supralabials was given as seven); one anterior temporal, long, directly above fifth and sixth supralabial; two posterior temporals, small, a little larger than the body scales.

Mental rounded anteriorly, definitely broader than long, separately from chinshields by first pair of infralabials; infralabials $7-7$, first four in contact with anterior chinshields; anterior chinshields longer than broad, in contact, a little longer than the posterior ones; posterior chinshields separated by gular scales; four rows of gulars separate the chinshields from first the ventral.

Dorsal scales 15 rows, smooth on body, but keeled on tail; ventrals 180 (180, 183); anal divided; subcaudals 70 (73, 69). Ventrals + caudals 250 (253, 252). Standard length (snout to vent) $448 \mathrm{~mm}(430,506 \mathrm{~mm})$, tail length $105 \mathrm{~mm}$ (117, $122 \mathrm{~mm})$; tail length as $\%$ of total length $19.0(21.4,19.4)$.

Coloration. In life, dorsal surface bright dark brown, orange spots on three to five dorsal scales of the fifth row from outer margin, but indistinct in posterior portion; ventral surface light yellow, dark mottling on subcaudals; lateral margin of ventral scales dark brown as on the dorsals; mental and upper anterior portion of first to fourth infralabials dark brown. The specimen preserved in alcohol (OPM $\mathrm{H}$ 665) lacks the orange color of the dorsal spots but retains the dark brown color. The holotype and OPM H 005 are preserved in formalin and their dorsal color is light brown.

Distribution and Habitat. Known only from the upper reaches of the Shirase-gawa River, Kume-jima Island $\left(26^{\circ} \mathrm{N}, 126^{\circ} \mathrm{E}\right)$, the Okinawa Group, Ryukyu Archipelago.

The site where the three specimens were collected is situated $1,000 \mathrm{~m}$ southeast of Mt. Uegusuku-dake $(309 \mathrm{~m})$ and is $100 \mathrm{~m}$ in altitude. The upper part of the Shirasegawa River flows through a forest of Pleioblastus linearis-Castanopsis sieboldii. The stream is shallow, less than $20 \mathrm{~cm}$ deep, and its bottom is covered with rocks and pebbles of andesite and tuff breccia. I captured the third specimen (OPM H 665) diving in the stream (water temperature, $24.5^{\circ} \mathrm{C}$ ) at $10: 00$ a.m.. The holotype was also collected under a rock in the water (K. Kikuzato, personal communication).

\section{Discussion}

No attempt was made by previous authors (Okada and Takara, 1958; Takara, 1962; Koba et al., 1959; Nakamura and Uéno, 1963), to examine the idea that "Opheodrys" kikuzatoi is a congener of Entechinus semicarinatus, but kikuzatoi is distinct from members of the genus Entechinus.

Cundall (1981) revised the genus Opheodrys and placed semicarinatus in En- 
techinus together with four other species. The genus Entechinus, as grouped by him (Cundall, op. cit.), corresponds to Eurypholis of Pope (1935). The members of the genus Entechinus (=Eurypholis) are characterized by greenish dorsal coloration (Pope, 1935), from which the dark brown color of kikuzatoi is quite different, as already pointed out by Nakamura and Uéno (1963). The head scales of kikuzatoi also differ from members of that genus, as noted in the original description, but the generic status of the species has never been thrown into doubt. "Opheodrys" kikuzatoi differs from all members of Entechinus in scutellation: single prefrontal, two preoculars, pentagonal frontal, dorsally directed nostrils and keeled caudal scales. In the original description, the prefrontal was counted as two, but this, in fact, is an abnormal condition. The unique condition of the nostrils was also neglected. All these differences indicate that kikuzatoi does not belong to Entechinus.

"Opheodrys" kikuzatoi has the characteristics of the members of the Chinese Opisthotropis as described below.

Head small, not distinct from neck; two internasals, their anterior margin narrow; nasal situated dorsally, nostril directed upward on antero-dorsal part of nasal; one broad prefrontal; eye small, pupil round or oval; body scales 15-19 rows, smooth or keeled; paired subcaudals. Most of the Chinese species are aquatic, living in mountain streams (Zhejiang Medical College et al., 1980), the same habitat as kikuzatoi. Considering all this evidence, it seems appropriate to place kikuzatoi in the genus Opisthotropis. Among the species of this genus, maxwelli seems at present closest to kikuzatoi, but these two species differ from each other in many respects. The outline of the genus Opisthotropis itself is far from clear (Brown and Leviton, 1961), and a revision of this genus, including kikuzatoi as a new member, is required.

\section{Acknowledgments}

I thank Kyoutatsu Kikuzato, Tetsuo Takara, Er-mi Zhao, Yasuhiko Shibata, and Hiroshi Takahashi for valuable information and advice. I also thank Fumiyasu Sato, Nobuki Iwatsuki, and Taiji Kurozumi for cooperation on collecting trips. Tsutomu Hikida, Masafumi Matsui, Showichi Sengoku, and Densaburo Ishimine reviewed my original MS. This work was supported in part by a research grant from the Ministry of Education of Japan, No (B) 57917049.

\section{Literature}

Brown, W.C. and A.E. Leviton 1961. Discovery of the snake genus Opisthotropis in the Philippine Islands, with description of a new species. Occ. Pap. Nat. Hist. Mus. Stanford Univ. 8: 1-5. 
Cundall, D. 1981. Cranial osteology of the Colubrid snake Genus Opheodrys. Copeia, 1981(2): 353-371. Koba, K., Y. Okada and S. Chinen 1959. Reptilia. Annotated List of Animals of the Okinawa Islands: 26-30. (in Japanese)

Nakamura, K. and S.-I. Uéno 1963. Japanese Reptiles and Amphibians in Colour. Hoikusha, Osaka. (in Japanese)

Okada, Y. and T. Takara 1958. A new species of Liopeltis (Ophidia, Colubridae) from Ryukyu Islands. Bull. Biogeogr. Soc. Japan, 20(3): 1-3. (in Japanese with English resumé)

Pope, C.H. 1935. The reptiles of China. Natural History of Central Asia, 10. Amer. Mus. Nat. Hist., New York.

Takara, T. 1962. Studies on the terrestrial snakes in the Ryukyu Archipelago. Sci. Bull. Agr. \& Home Econ. Div. Univ. Ryukyus., 9: 1-202. (in Japanese with English resumé)

Zhejiang Medical College, Chengdu Institute of Biology, Shanghai Museum of Natural History and Zhejiang Provincial Medical Institute (ed.) 1980. An illustrated monograph of Snakes of China. Shanghai-kexue-jishu-chubanshe, Shanghai. (in Chinese)

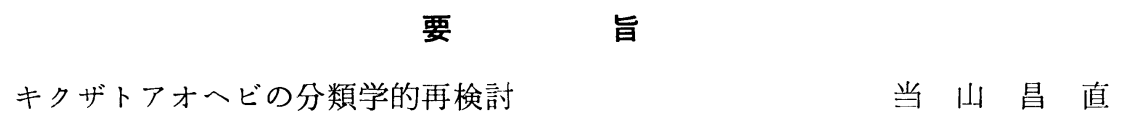

沖縄県久米島からの一個体の標本に基ついて記載され，その後記録のなかったキクザトアオ ヘビの分類学的再検討を，模式標本に加えて，新たに採集された 2 個体を用いて抗なった。 本種は緑色を呈しない等，アオへビ属（Opheodrys ないしEntechinus）と合致しない特徴が 多く，属の変更が必要と考えられた。本種は中国産のOpisthotropis 属の諸種と多くの形態的 特徴で一致しており,さらに溪流中に生活するという生態的特徵でも一致したため, 本種をこ の属に帰属させるのが妥当と考えた。 